\title{
POSSIBILITY OF APPLYING CONTEMPORARY ANALYTICAL METHODS IN AUDITING PROCUREMENTS OF AGRICULTURAL COMPANIES
}

\author{
Milan Mihajlović ${ }^{1}$, Marko Špiler ${ }^{2}$, Jelena Avakumović3, Svetlana Tasić4, \\ Dejan Vukosavljevićs , Snežana Krstićc \\ *Corresponding author E-mail: milan.mih83@gmail.com
}

\begin{tabular}{l} 
A R T I C L E I N F O \\
Review Article \\
Received: 27 September 2020 \\
Accepted: 04 January 2021 \\
doi:10.5937/ekoPolj2101191M \\
UDC 303:657.631.8]:631.164.6 \\
\hline
\end{tabular}

Keywords:

public procurement, performance audit, data mining, agricultural company

JEL: F14, P52

\section{A B S T R A C T}

Despite the significant results that State Audit Institution achieved in the domain of determining regularities of doing business and truthfulness of financial reports of budget users, performance audit was given significantly less attention, which points to the necessity of developing a methodology for this discipline, as well as a technique to apply it. This contribution represents an attempt to apply a technique of finding hidden knowledge-implicit knowledge (Data mining - DM) in the process of auditing public procurement procedures and illustrating the significance of developing a technique for assessing the purposefulness of using budget assets on an example of public procurements performed in an agricultural company.

(C) 2021 EA. All rights reserved.

1 Milan Mihajlović, Ph.D., Assistant Professor, Military Academy, University of Defence, Pavla Jurišića Šturma 33, Belgrade, Republic of Serbia, Phone: +381 643021 951, E-mail: milan. mih83@gmail.com, ORCID ID (https://orcid.org/0000-0001-7949-2631)

2 Marko Špiler, Ph.D., Assistant Professor, Faculty of Management, Union - Nikola Tesla University, Njegoševa 1a, 21205 Sremski Karlovci, Serbia, Phone: +381 642480 025, E-mail: mspiler@cmn.rs, ORCID ID (https://orcid.org/0000-0001-6319-2597)

3 Jelena Avakumović, Ph.D., Assistant Professor, Faculty of Management, Union - Nikola Tesla University, Njegoševa 1a, 21205 Sremski Karlovci, Serbia, Phone: +381 6947 75 447, E-mail: jelena.avakumovic@famns.edu.rs ORCID ID (https://orcid.org/0000-0002-7856-8064)

4 Svetlana Tasić, Ph.D., Assistant Professor, Faculty of Management, Union - Nikola Tesla University, Njegoševa 1a, 21205 Sremski Karlovci, Serbia, Phone: +381 607112 711, E-mail: cecatasic1@gmail.com, ORCID ID (https://orcid.org/0000-0003-3049-6396)

5 Dejan Vukosavljević, Ph.D., Assistant Professor, Faculty of Management, Union - Nikola Tesla University, Njegoševa 1a, 21205 Sremski Karlovci, Serbia, Phone: +381 63203 300, E-mail: dejan.vukosavljevic@famns.edu.rs, ORCID ID (https://orcid.org/0000-0001-74752764)

6 Snežana Krstić, Ph.D., Associate Professor, Military Academy, University of Defence, Pavla Jurišića Šturma 33, 11000 Belgrade, Serbia, E-mail: snezanakrstic17@gmail.com ORCID ID (https://orcid.org/0000-0001-6666-6401) 


\section{Introduction}

Performance audit is the way in which taxpayers, financiers, legislators, executive authority, regular citizens and media gain an ability to control public funds (Vidovič, \& Milunović, 2017; Pavlović \& Čelić 2020; Milojević et al., 2020) and see the effects of operations within different government activities. Such audit reports contain answers to questions, for example: "Could the money have been spent better?"

Performance audit is searching for an answer to two basic questions (Arens, Elder \& Beasley, 2014): Was everything done in the right way (were the business politics decisions conducted correctly)? Was the right thing done (were the appropriate politics implemented in an adequate way)? From the practical experience of an auditor, irregularities and corruptive activities most often happen in the domain of public procurements, which deserves a more detailed analysis to be performed in this area by applying more contemporary methods.

Public procurement audit can be conducted as an individual task or as a part of a more complex audit. Within auditing public procurements, an auditor can decide to only revise a contract or review an entire public procurement procedure (Stanojević, Vidovič, 2014).

This paper represents possible public procurement auditing methods, which are as a rule, applied by state auditors when auditing public sector users. According to that, solutions that are established by the current Law on Public Procurements (LPP) will be taken into consideration, as well knowledge of several world auditing institutions on auditing public procurements.

Public procurements represent a procedure in which public sector subjects - contracting authorities perform procurement of goods, works and services. LPP ("Off. Herald of RS”, No. 91/2019) defines public procurement as procurement of goods, services or works by the contracting authority, in the manner and under conditions defined by this Law. Certain principles apply for public procurements. One of the basic principles is ensuring competition among bidders. In rare cases LPP allows contracting authorities to enter into a contract directly with the contractor, without conducting an open public procurement procedure. Competition in public procurement signifies equal treatment of all bidders, fairness and honesty when applying the criteria, as well as consistent application of regulations regarding protection of competition. Contracting authorities must ensure lawful, economical and efficient use of public assets when conducting public procurements (Picard, \& Rusli, 2018). Well and clearly defined public procurement system can greatly contribute to improvement of public services, reduction of business costs and prevention of inefficient use of public assets and thus indirectly improve competitiveness of the state (Stanojević, \& Milunović, 2020; Vujić et al., 2020).

Public procurement process begins by identifying the needs and ends by concluding a contract or by expiration date of a public procurement object. If conducted by the current Law, public procurement procedure enhances business of the entire public 
sector contracting authorities, considering that the main goal of LPP is to ensure economic use of public assets, taking into consideration the purpose and the object of public procurement. Well planned works, then procurement of goods and services, as well as correctly conducted public procurement procedures can contribute to significant savings for the contracting authority.

Each public procurement evaluated as medium or high level of risk, as well as high value public procurements are defined as projects. Roles and jurisdictions of all personnel included in the public procurement procedure (Engel, Fischer, \& Galetovic, 2013) are clearly defined and agreed upon, so everyone knows their roles and what is to be expected of them. All phases in the public procurement process are clearly defined in written form (Farooq, \& Shehata, 2018; Grbić \& Jovanović 2020).

Main goal of good management in public procurements is achieving results that were planned within the decision on conducting the public procurement procedure. The contracting authority determines the object of public procurement, i.e. what is expected from the supplier, as well as a way of evaluating achieved results. Clearly defined contractual provisions enable the contracting authority, contractor and auditor to reveal and correctly define each deviation from the contract more easily. Good management practice with contracts includes ongoing cost control, because inadequate management can easily lead to overdrafts of contracted amounts, while good management can lead to savings.

When conducting public procurement, all contracting authorities are obliged to respect basic principles of public procurements defined in LPP, as well as good practice. Among the principles of public procurements are:

- $\quad$ Principle of Efficiency and Cost-Effectiveness

- $\quad$ Principle of Ensuring Competition

- Principle of Transparency in Public Procurement Procedure

- $\quad$ Principle of Equality of Bidders.

The aforementioned principles are the basis for good practice in conducting public procurements.

\section{Auditing public procurements of agricultural companies owned by the state}

The auditor (Milojević, Andžić, \& Vladisavljević, 2018) questions the regularity of public procurement procedures in all defined phases. Thereby, more attention is paid to some phases depending on how materiality is defined and how it's decided to assess irregularity (Duin, i dr., 2017; Pešić, \& Miljković, 2020). For example, the auditor can check in detail the application of criteria, evaluation of bids and choosing the most favorable bidder, without checking whether the contracting authority sent the notification on concluded public procurement contract (Vasić, 2015). The range and debt of research depend on audit goals and types of public procurement procedures 
(Eilifsen, et al., 2014; Stanojević, \& Vidovič, 2014). In public procurements where the Law is applied, auditing is more complex and demands more time related to public procurements exempt from the Law. The auditor must primarily separate investments (Mićović, \& Miletić, 2019), procurement of goods or services that are, or aren't exempt from the law. In public procurements (Milojević, Obradović, \& Nešić, 2018) that aren't exempt from the law (Kostić, 2020) the auditor must check the regularity of the procedure that the audit subject is obliged to conduct in accordance with the LPP.

The auditor initiates the public procurement audit procedure within audited subject (Milojević, \& Mihajlović, 2019; Savić, \& Milojević, 2019) by determining the existence of control, testing business effectiveness and based on risk assessment determines the approach that he will apply when conducting the auditing tasks.

In our article the emphasis is on analyzing public procurements from the aspect of attributive qualification of public procurements, as a basis for applying DM techniques and analyzing results with the purpose of illustrating one of the techniques and methods of performance audit (cost benefit, Monte Carlo, Delphi method, Discrete process method etc.), which is in our case DM.

\section{Applying DATA MINING in analyzing public procurements}

Researching data (data mining) includes the application of machine learning methods as a special area of Artificial Intelligence, and it relates to development of algorithms and techniques that enable computers to "learn", as well as other methods for finding samples in observed data. Data mining is also known as a process of Knowledge-Discovery in Databases (KDD) or Knowledge-Discovery and Data Mining (Bejju, 2016).

All data mining methods use learning based on induction. This is a process of defining general conceptual definitions by observing specific examples from which one learns inductively with the help of a teacher (Supervised learning), a type of learning performed based on classified examples, i.e. decisions made.

Induction or inductive learning is also sometimes called inductive logic, a process of making decisions in which the premises of an argument support the conclusion, but don't guarantee it. Inductive learning of concepts is a machine learning form whose goal is induction of description of concepts (category, class of objects), which are understandable to people dealing with a particular issue, i.e. those that correspond to concepts that a person would produce when considering the same entities (Milojević, et al., 2020).

Basic techniques of data mining are decision tree, association rules, closest point algorithm and genetic learning. Production rules, decision lists and decision trees are examples of understandable way of representing empirical knowledge.

Inductive learning methods are used in researching data because they give understandable results that can be directly interpreted. Prediction accuracy of these methods is also high and can be compared with the most successful methods of inductive learning. 
It should be mentioned precisely here what a computer can learn. Learning is a complex process. We can defined four levels of learning: Facts - Facts are simply stating the truth, Concepts - Concepts are a set of objects, symbols or events grouped together because they share certain characteristics, Procedures - Procedures are a flow of actions in order to reach a goal, and Principles - Principles or rules of behavior represent the greatest level of learning. Those are general truths or laws that are the basis for other truths.

The aforementioned learning procedures can be conducted in two cases:

- Supervised learning and

- Unsupervised learning.

Supervised learning is a machine learning technique based on a data set that is called training data. Training data consists of input objects and desired outputs. The output function can have a continuous value (called regression) or it can predict the class of input objects (called classification). Basic goal of such learning is predicting the value of an output function for each valid input object after seeing a certain number of examples of such instances (with certain input and output values) (Zhenhua, Nobuhiko, \& Jonathan, 2016).

Most often, supervised learning generates a global model that maps input objects to desired outputs. In some cases, furthermore, the map is implemented as a set of local models.

In an aim of solving supervised learning problems, there are certain steps (Agresti, 2002):

- Determining the example type for learning. Determining the type of data in our case are quantitative data on internal control in IT surroundings.

- Gathering a training set. Data on completeness, accuracy and promptness of data in IT processing.

- Determining input characteristics. Number of characteristics describing the object.

- Determining the corresponding learning algorithm. For example, neuron networks, decision trees, etc.

- Completed plan. Run the chosen learning algorithm on the collected training set. Parameters of the learning algorithm can be set by optimizing performances on a subset of the training set (validation set) or by cross-validation.

Unsupervised learning is different from supervised learning because it doesn't have a priority output. A set of input objects was gathered and unsupervised learning treats a set of input objects as a set of random variables.

In the following part of the paper we will try to sublimate the given premises on an example of applying multivariate discriminant analysis (Stanišić, \& Stanojević, 2009).

Statistical technique defined as multivariate linear discriminant analysis is developed in the 1930's as a statistical category, that formally-quantitatively performs discrimination http://ea.bg.ac.rs 
among classes of biological and other phenomena and observations associated with them (Ismail et al., 2015). Soon these researches began application in other areas, especially economy. A series of papers were recorded in the domain of analyzing government bond quality rankings, determining credit potential of banks and their clients, classifying errors in the domain of accounting - business transactions, etc. In time this technique became a standard asset in economy, as well as accounting and auditing expertise. However, application of discriminant analysis in context of finding hidden (implicit) knowledge (data mining) has a special dimension because the analysis isn't reduced to applying the model but rather Supervised learning is performed on a sample of discriminant analysis model on several occasions so the solution would be more accurate.

\section{Case study of applying DATA MINING in auditing agricultural company procurements}

Let us assume that the following parameters were determined in the public procurement procedure:

Table 1. Model parameters

\begin{tabular}{|l|l|l|}
\hline $\begin{array}{l}\text { Modalities of public } \\
\text { procurement defined } \\
\text { Type of procedure }\end{array}$ & $\begin{array}{l}\text { Number of participants in public } \\
\text { procurement }\end{array}$ & $\begin{array}{l}\text { Disclosed value for public } \\
\text { procurement }\end{array}$ \\
\hline Competitive dialogue & Small number of participants & Small \\
\hline Competitive dialogue & Small number of participants & Small \\
\hline Competitive dialogue & High number of participants & Medium \\
\hline Competitive dialogue & High number of participants & Small \\
\hline Restrictive procedure & Small number of participants & Medium \\
\hline Restrictive procedure & Small number of participants & Small \\
\hline Restrictive procedure & High number of participants & Large \\
\hline Restrictive procedure & High number of participants & Medium \\
\hline Open procedure & Small number of participants & Large \\
\hline Open procedure & Small number of participants & Medium \\
\hline Open procedure & High number of participants & Large \\
\hline Open procedure & High number of participants & Large \\
\hline
\end{tabular}

Source: Authors' calculations

Thus formed table deserves a special comment. Primarily it was taken with the purpose of illustrating relations between: modalities of public procurement determined by the type of procedure, number of participants and disclosed available budget, i.e. value of public procurement. Illustrative sample is on twelve modalities of relations between these three variables.

Public procurement modalities determined by the participants vary for the needs of this research in the domain of performance audit on three levels: open procedure, restrictive procedure and competitive dialogue. 
Number of participants in the public procurement procedure vary in two domains: small and high number of participants.

Size of available budget - value of public procurement is a target variable that contains certain relationship between public procurement modalities determined by the type of procedure and number of participant in the public procurement procedure. A research question arises, what is the relation-codependence between these three variables and what can be used to measure their connection. More precisely, how publicly disclosed budget for a specific public procurement defines-influences the number of participants, as well as their predestination for the offered value of the public procurement project.

Furthermore, one of the essential determinations is what DM technique is adequate for assessing interrelations between attributive-descriptive variables. We decided to use the discriminant correspondence analysis (DCA).

\section{Discriminant correspondence analysis}

Output is based on results of correspondence analysis but they are presented differently. Without getting into statistical explanation, we will clarify the results.

Matrix trace $=0.39583$ - indicates the amount of information that can be modeled between Target variable (Budget) and other two variables (type of procedure and number of participants)

Table 2. Results of the analysis

\begin{tabular}{|c|c|c|c|c|c|}
\hline \multirow{2}{*}{ Factor } & \multirow{2}{*}{$\begin{array}{c}\text { Canonical } \\
\text { correlation R }\end{array}$} & \multirow{2}{*}{ Square R } & \multicolumn{3}{|c|}{ Explanation (between) variations } \\
\cline { 4 - 6 } & & $\begin{array}{c}\text { Characteristic } \\
\text { values }\end{array}$ & Proportion (\%) & $\begin{array}{c}\text { Cumulative } \\
\text { (\%) }\end{array}$ \\
\hline $\mathbf{1}$ & 0.8539 & 0.7292 & 0.36458 & 92.11 & 92.11 \\
\hline $\mathbf{2}$ & 0.2500 & 0.0625 & 0.03125 & 7.89 & 100.00 \\
\hline \multicolumn{3}{|c|}{ Tot. } & Tot. & $\mathbf{0 . 3 9 5 8 3}$ & 100.00 \\
\hline
\end{tabular}

Source: Authors' calculations

Characteristic values $(\lambda)$ indicate how much potential factors depend on the size of the budget (Berkhin, 2006). In our case the first and the second one together are: $0.36458+0.03125=0.39583$

Correlation relationship (square root $\mathrm{R}$ ) is the relationship between variations of group affiliation (for example $\lambda_{1}=0.36458$ ) and total factor variances. For the first factor the value is $\eta_{1}^{2}=0.7292$, i.e. $72.92 \%$ of dispersion is explained.

Finally, canonical correlation is $\eta_{1}=\sqrt{ } \eta_{1}^{2}=\sqrt{ } 0.7292=0.8539$.

Table that shows group medium for each factor 
Table 3. Group medium for each factor

\begin{tabular}{|l|l|l|l|l|l|l|l|l|l|}
\hline \multicolumn{4}{|c|}{ Characterization } & \multicolumn{3}{c|}{ Coord. } & \multicolumn{2}{c|}{$\begin{array}{c}\text { Contribution } \\
\text { (\%) }\end{array}$} & \multicolumn{3}{c|}{ COS } \\
\hline Values & Weight & Sq. Dist. & Inertia & coord 1 & coord 2 & ctr 1 & ctr 2 & cos 1 & cos 2 \\
\hline Large & 0.33333 & 0.56250 & 0.18750 & 0.73951 & -0.12500 & 50.0 & 16.67 & $0.97(0.97)$ & $0.03(1.00)$ \\
\hline Small & 0.33333 & 0.56250 & 0.18750 & -0.7395 & -0.12500 & 50.0 & 16.67 & $0.97(0.97)$ & $0.03(1.00)$ \\
\hline Medium & 0.33333 & 0.06250 & 0.02083 & 0.00000 & 0.25000 & 0.00 & 66.67 & $0.00(0.00)$ & $1.00(1.00)$ \\
\hline
\end{tabular}

Source: Authors' calculations

Without getting into detailed statistical explanation we will point to the fact that the size of the budget is of influence and in our case Large budget - open procedure mostly on determining selection modalities by the participants. On the other hand, there a paradoxal situation in competitive dialogue, with a negative relation in the same amount compared to open procedure, but with a contribution of $50 \%$ compared to $50 \%$. While the contribution of restrictive procedure is significantly smaller $25 \%$ and grouped in the second factor.

\section{Canonical structure}

Canonical structure shows the coordinates and the influence of factors - descriptive values with the aim of determining the factors and their influence. Namely, it allows for an explanation of differences between modalities and target attribute (budget).

It is visible in the table that type of procedure offered by participants corresponds to the size of the budget and is of dominant significance, however the number of participants isn't significant for participation in public procurements. Regarding the number of participants, the number is even for small and large budget.

Table 4. Results of the analysis

\begin{tabular}{|l|l|l|l|l|l|l|l|l|l|c|}
\hline \multicolumn{4}{|c|}{ Characterization of rows } & \multicolumn{2}{c|}{ coord. } & \multicolumn{3}{c|}{ Contributions (\%) } & COS \\
\hline Values & Weight & Sq. Dist. & Inertia & coord 1 & coord 2 & ctr 1 & ctr 2 & cos 1 & cos 2 \\
\hline $\begin{array}{l}\text { Type of procedure }= \\
\text { competitive dialogue }\end{array}$ & $\mathbf{0 . 1 6 6 6 7}$ & $\mathbf{0 . 8 7 5 0 0}$ & $\mathbf{0 . 1 4 5 8 3}$ & -0.91856 & -0.176 & 38.6 & 16.7 & $0.96(0.96)$ & $0.04(1.00)$ \\
\hline $\begin{array}{l}\text { Type of procedure }= \\
\text { restrictive procedure }\end{array}$ & $\mathbf{0 . 1 6 6 6 7}$ & $\mathbf{0 . 1 2 5 0 0}$ & $\mathbf{0 . 0 2 0 8 3}$ & 0.00000 & 0.353 & 0.0 & 66.7 & $0.00(0.00)$ & $1.00(1.00)$ \\
\hline $\begin{array}{l}\text { Type of procedure }= \\
\text { open procedure }\end{array}$ & $\mathbf{0 . 1 6 6 6 7}$ & $\mathbf{0 . 8 7 5 0 0}$ & $\mathbf{0 . 1 4 5 8 3}$ & 0.91856 & -0.176 & 38.6 & 16.7 & $0.96(0.96)$ & $0.04(1.00)$ \\
\hline $\begin{array}{l}\text { Number of } \\
\text { participants in public } \\
\text { procurement = small }\end{array}$ & $\mathbf{0 . 2 5 0 0 0}$ & $\mathbf{0 . 1 6 6 6 7}$ & $\mathbf{0 . 0 4 1 6 7}$ & -0.40825 & 0.000 & 11.4 & 0.0 & $1.00(1.00)$ & $0.00(1.00)$ \\
\hline $\begin{array}{l}\text { Number of } \\
\text { participants in public } \\
\text { procurement = high }\end{array}$ & $\mathbf{0 . 2 5 0 0 0}$ & $\mathbf{0 . 1 6 6 6 7}$ & $\mathbf{0 . 0 4 1 6 7}$ & 0.40825 & 0.000 & 11.4 & 0.0 & $1.00(1.00)$ & $0.00(1.00)$ \\
\hline
\end{tabular}


Table 5. Canonical coefficients

\begin{tabular}{|l|c|c|}
\hline \multicolumn{1}{|c|}{ Attributive value } & Factor 1 & Factor 2 \\
\hline Type of procedure $=$ competitive dialogue & -0.7606388 & -0.4999999 \\
\hline Type of procedure $=$ restrictive procedure & 0.0000000 & 1.0000001 \\
\hline Type of procedure $=$ open procedure & 0.7606388 & -0.4999999 \\
\hline Number of participants in public procurement $=$ small & -0.3380617 & 0.0000001 \\
\hline Number of participants in public procurement $=$ high & 0.3380617 & 0.0000001 \\
\hline
\end{tabular}

Source: Authors' calculations

Canonical coefficients point to domination of size of public procurement, more precisely the frequency of participating in public procurements when it's about public procurements with an open procedure, but at the same time an analogous structure is formed, the number of participants is same in a competitive dialogue.

\section{Conclusions}

The example is extremely simplified and illustrative but it talks about possible predestinations of participants in public procurements. Who will offer a smaller amount or apply i.e. offer to do the business for smaller amounts, which may be unrealistic or vice versa offer to do business for unrealistically large amounts. In our case the grouping, regardless of the procedure type and number of participants, indicates that the public procurement procedure, when we talk about public procurement modalities determined by the number of participants variating from small, medium or high, has a distinctively negative correlation depending on the budget concentrated on the competitive dialogue, meaning a smaller number of offered public procurements in competitive dialogue, bigger number of applying participants. In case of public procurement offered in open procedure, a positive correlation occurs, generating a high number of bidders. For our simplified example, it's interesting that the negative and positive canonical structure of contributions is the same and amounts to + and -0.91856 , which points to a dominance of competitive dialogue and open procedure when conducting public procurement, while the other factor with smaller value determines and relates to public procurement modalities determined by participants as medium contribution value is 0.3555 . The essence of the contribution is to point to a possibility of characteristic of number of participants on public procurement modalities, as well as a number of participants (low, high) is in accordance with budget resources. The example is extremely simplified but it clearly illustrates the possibility of applying this method, which clearly points to hidden information in many areas of spending budget assets where Data Mining is of inestimable importance.

\section{Conflict of interests}

The authors declare no conflict of interest. 


\section{References}

1. Agresti A. (2002). Categorical Data Analysis 2nd ed., Wiley, New York.

2. Arens, A.A., Elder, R.J., \& Beasley, M.S. (2014). Auditing and assurance services. Global Edition.

3. Berkhin, P. (2006). A survey of clustering data mining techniques. In Grouping multidimensional data, 25-71. https://doi.org/10.1007/3-540-28349-8_ 2

4. Bejju A. (2016). Sales Analysis of E-Commerce Websites using Data Mining Techniques. International Journal of Computer Applications, 133(5), 36-40. https://doi.org/10.5120/ijca2016907812

5. Duin, D., Krstić, D., Nešić, B., \& Kaluđerović, N. (2017). Revizija svrsishodnosti javnih nabavki budžetskih korisnika. Oditor-časopis za menadžment, finansije $i$ pravo, 3(3), 61-72. [in English: Duin, D., Krstić, D., Nešić, B., \& Kaluđerović, N. (2017). Audit of the expediency of public procurement of budget users. OditorJournal of Management, Finance and Law, 3 (3), 61-72.]

6. Eilifsen, A., Messier, W.F., Glover, S.M., \& Prawitt, D.F. (2014). Auditing and assurance services (3rd international ed.). London: McGraw-Hill.

7. Engel, E., Fischer, R.D., \& Galetovic, A. (2013). The basic public finance of public-private partnerships. Journal of the European Economic Association, 11(1), 83-111. https://doi.org/10.2307/23355049

8. Farooq, O., \& Shehata, N. F. (2018). Does external auditing combat corruption? Evidence from private firms. Managerial Auditing Journal, 33(3), 267-287.

9. Grbić, M., \& Jovanović, D. (2020). Comparative financial systems: Implications for economic growth. Oditor-časopis za menadžment, finansije i pravo, 6(1), 4965. https://doi.org/10.5937/Oditor2001046G

10. Ismail M., Ibrahim M., Sanusi Z., \& Cemal Nat N. (2015). Data Mining in Electronic Commerce: Benefits and Challenges. International Journal of Communications, Network and System Sciences, 8(12), 501-509. https://doi. org/10.4236/ijens.2015.812045

11. Kostić, R. (2020). Revizija ostvarivanja ciljeva budžetskih programa. Održivi razvoj, 2(1), 41-52. https://doi.org/10.5937/OdrRaz2001041K[in English: Kostic, R. (2020). Audit of achieving the goals of budget programs. Sustainable Development, 2 (1), 41-52.].

12. Mićović, S., \& Miletić, J. (2019). Poslovni subjekt kao osnova održivosti razvoja. Održivi razvoj, 1(1), 43-51. https://doi.org/10.5937/OdrRaz1901043M[in English: Mićović, S., \& Miletić, J. (2019). Business entity as a basis for sustainable development. Sustainable Development, 1 (1), 43-51].

13. Milojević, I., Andžić, R., \& Vladisavljević, V. (2018). Accounting aspects of auditing the budget system. Economics of agriculture, 65(1), 337-348. https://doi. org/10.5937/ekoPolj1801337M 
14. Milojević, I.M., Obradović, B.V., \& Nešić, B. (2018). Nabavka kao predmet revizije. Vojno delo, 70(2), 351-359. https://doi.org/10.5937/vojdelo1802351M [in English: Milojević, IM, Obradović, BV, \& Nešić, B. (2018). Procurement as a subject of audit. Military Work, 70 (2), 351-359]

15. Milojević, I., \& Mihajlović, M. (2019). Primena metoda ocene investicionih projekata u javnom sektoru. Oditor, 5(1), 19-31. https://doi.org/10.5937/Oditor1901019M [in English: Milojević, I., \& Mihajlović, M. (2019). Application of methods for evaluating investment projects in the public sector. Oditor, 5 (1), 19-31]

16. Milojević, I., Mihajlović, M., Popović, M., \& Pantić, N. (2020). Application of quantitative models in the organization of the financial function of agricultural enterprises. Economics of agriculture, 67(3), 747-762. https://doi.org/10.5937/ ekoPolj2003747M

17. Milojević, I., Mihajlović, M., \& Pantić, N. (2020). Collection and documentation of audit evidence. Oditor-časopis za menadžment, finansije i pravo, 6(2), 77-90. https://doi.org/10.5937/Oditor2002077M

18. Pavlović, N., \& Čelić, I. (2020). The analysis of competitive strategies from the perspective of small and medium enterprises. Hotel and Tourism Management, 8(1), 101-110. https://doi.org/10.5937/menhottur2001101P

19. Pešić, H., \& Miljković, M. (2020). Održivost budžetskih načela i procedura. Održivi razvoj, 2(2), 15-29. https://doi.org/10.5937/OdrRaz2002015P[in English: Pešić, H., \& Miljković, M. (2020). Sustainability of budget principles and procedures. Sustainable Development, 2 (2), 15-29.]

20. Picard, P.M., \& Rusli, R.D. (2018). State-owned firms and private debt. J. Public Econ. Theory, 20(5), 672-702 https://doi.org/10.1111/jpet.12297

21. Savić, B., \& Milojević, I. (2019). Izazovi i dometi revizije prihoda. Vojno delo, 71(7), 394-403. https://doi.org/10.5937/vojdelo1907394S [in English: Savić, B., \& Milojević, I. (2019). Challenges and scope of revenue auditing. Military Work, 71 (7), 394-403.]

22. Stanišić, M., \& Stanojević, Lj. (2009). Revizija i primena kompjutera. Cicero print, Čugura, Beograd. [in English: Stanisic, M., \& Stanojevic, Lj. (2009). Computer revision and application. Cicero print, Čugura, Belgrade.]

23. Stanojević. Lj., \& Vidovič, Z. (2014). Revizija javnog sektora. Poslovni Biro, Beograd. [in English: Stanojevic. Lj., \& Vidovič, Z. (2014). Public sector audit. Business Bureau, Belgrade.]

24. Stanojević, S., \& Milunović, M. (2020). Okončanje postupka državne revizije. Akcionarstvo, 26(1), 35-48. [in English: Stanojević, S., \& Milunović, M. (2020). Completion of the state audit procedure. Shareholding, 26 (1), 35-48.]

25. Vasić Z. (2015). Poreska kontrola uslov funkcionisanja budžetskog sistema. Akcionarstvo, 21(1), 5-22. [in English: Vasić Z. (2015). Tax control is a condition for the functioning of the budget system. Shareholding, 21 (1), 5-22.] 
26. Vidovič, Z., \& Milunović, M. (2017). Revizija svrsishodnosti poslovanja. Oditor, 3(2), 37-53. [in English: Vidovič, Z., \& Milunović, M. (2017). Business purpose audit. Auditor, 3 (2), 37-53]

27. Vujić, M., Sekulić, D., \& Cvijanović, D. (2020). The importance of intangible elements in the assessment of service quality in hotels in Kolubara District. Hotel and Tourism Management, 8(2), 43-52. https://doi.org/10.5937/menhottur2002043V

28. Zakon o javnim nabavkama ("Sl. glasnik RS", 91/2019). [in English: Law on Public Procurement ("Official Gazette of RS", 91/2019).]

29. Zhenhua, C., Nobuhiko, D., \& Jonathan G.L. (2016). Data review of transportation infrastructure public-private partnership: a meta-analysis. Transport Reviews, 36 (2), 228-250. https://doi.org/10.1080/01441647.2015.1076535 